\title{
"An Empirical Research on Student's Usage of Social Networking Towards Professional Grooming with Reference to Ramapuram at Thiruvallur District"
}

\author{
S.Purushothaman, R.K. Sugashini
}

\begin{abstract}
In Today's digital world the younger generation interested to learn and participate in the activities only through the Online mode and most of their time is also been spent on the social networking. This study focuses on identify the student's perception and their usage of social networking for the professional grooming such as for getting job opportunities, ideas on new courses, skill development trainings offered, connect with field expertise, social news and trending technology updates on daily basis.Due to the above reasons the students use the social networking and also make positive relationships with other students across the state and country for social interactions \& Interest of their choice. Through the study we can also identify the most useful social networking sites for the students in terms of their career advancement and professional growth. The social networking also helps in the transfer of knowledge to a huge groups and which helps the students group to learn new things in their field. The social networking also makes the students to unite them for the good social causes.

A sample of 158 students from various disciplines were taken for the study and they act as a representative of the student community in the Thiruvallur District. Through the questionnaire method the responses were collected and Statistical tools were applied for the analysis. The tools such as Percentage analysis, Correlation, Regression and one-wayANOVA used for the study. Based on the analysis the suggestions were given for the study.
\end{abstract}

Key words: Social networking, Student, Professional, Knowledge, Skills, Groups.

\section{INTRODUCTION}

In the Digital world people tend to show more interest towards connecting to each other through the social networking instead of direct face to face meetings. As it connects them with various relationships which grows and ends on social media itself. Some of the social networking sites gives enormous scope for learning new things to the people and some have become the addict which spoils the young minds. The scope of the study is done only on the good aspects of grooming the student community and giving awareness about the social networking with benefits to them. Nowadays even small business or big giants use the social networking as one of the platform to interact with the customers as well promote their products and services to the external world.

Revised Manuscript Received on September 10, 2019.

Mr.S.Purushothaman, Asst professor- MBA, Easwari Engineering College,Ramapuram, Chennai, Tamilnadu, India.

(email: purushothaman.s@eec.srmrmp.edu.in)

Ms. R.K. Sugashini, IInd year-MBA, Easwari Engineering College,Ramapuram, Chennai, Tamilnadu, India.
Thera are various Social networking through internet available for the connects which is very easy to use and able to reach many people in few seconds. Here for the study the focus is done only towards the professional grooming social networking sites for the students. Here are few networking sites and apps which brings them the world closer than ever by their enormous information and content uploaded for the users.

1. LinkedIn: It is used to connect with the people working in similar industries, professionals in various fields and sharing business related information to the people. It is also used as a portal for job finder.

2. Google+: A popular social media site which has 418 active million users across the world.

3. YouTube: The largest used video based social media website created for the people. This sites displays videos on any topics needed right from education, cooking, fitness, technical products etc.

4. Pinterest: It is the new site for the social networking users which used to pin the business bulletin content to the users. It also helps to get new ideas for the projects.

5. Quora: This social networking involves in sharing questions and answers will be given by the experts.

6. Bizsugar: It is the social networking site for the niche resources and small business owners.

7. Skype: It is the most popular communication site used by people for Voice calls, Video callsand text messaging. It is also used to conduct group conference calls.

8. Snapshot: social messaging site used to chat with friends and allows to explore latest news and even check out live stories happening in the world.

9. Live Journal: It is helps to maintain the user dairy, blog or journal along with privacy controls.

10. Research gate: it is used for share and discover research articles in various disciplines of Engineering \& Technology and also Management topics.

Apart from this the most entertainment oriented social networking and where maximum users viewing sites on a daily basis are Facebook, Instagram, Twitter and Blogs.

The word social networking means the dedicated websites used to interact with each other using an online platform. It also used share massages, share photos, do chats, give comments, support \& promote events and even upload 
“An Empirical Research on Student's Usage of Social Networking Towards Professional Grooming with Reference to Ramapuram at Thiruvallur District"

innovative ideas to the known groups and to the public.

The students should be trained on various aspects to equip themselves with business challenges needed for the current job market as an employee or employer. Thus the social networking will help the students to connect lively on daily basis with various field experts, senior professionals, achievers/ Celebrities and young entrepreneurs. Thus the current updates and information is possible only through the social networking media. The challenge faced by social networking site was about its usage and ithas to be handled correctly for good purpose and for individual growth not pertaining to hurt the individuals or society.

\section{OBJECTIVES OF THE STUDY}

1. To identify the perception of students about social networking sitesfor professional grooming.

2. To Rank the most preferred social networking sites among students.

3. To correlate with the student's education and purpose for using social networking.

4. To create awareness about the social networking and its benefits.

\section{SCOPE OF THE STUDY}

The students should get more awareness onthe usage of social networking sites for getting their benefits towards education and professional grooming. The contents and Information displayed will be more informative to the upcoming generations. In current scenario there is more scope for new social networking sites targeting students related to the professional grooming and Education. It is the responsibility of the educators to mentor the students on the benefits of social networking, which can be used for connecting students onresearch, projects and technical learnings supporting their courses.

\section{DATAANALYSIS \& RESULTS}

The data collected were analyzed using SPSS and consolidation given below.

TABLE1: Purpose of using Social networking by students

\begin{tabular}{|l|r|r|r|r|r|}
\hline \multicolumn{2}{|c|}{ Respondents opinion } & Frequency & Percent & $\begin{array}{c}\text { Valid } \\
\text { Percent }\end{array}$ & $\begin{array}{c}\text { Cumulative } \\
\text { Percent }\end{array}$ \\
\hline Valid & $\begin{array}{c}\text { Awareness on social } \\
\text { issues }\end{array}$ & 34 & 21.5 & 21.5 & 21.5 \\
\hline & Expertise connect & 2 & 1.3 & 1.3 & 22.8 \\
\hline & Friendship connect & $\mathbf{6 6}$ & $\mathbf{4 1 . 8}$ & $\mathbf{4 1 . 8}$ & $\mathbf{6 4 . 6}$ \\
\hline & Idea on courses & 6 & 3.8 & 3.8 & 68.4 \\
\hline & Job opportunities & 9 & 5.7 & 5.7 & 74.1 \\
\hline & Technology updates & 39 & 24.7 & 24.7 & 98.7 \\
\hline & 2 & 1.3 & 1.3 & 100.0 \\
\hline \multicolumn{7}{|c|}{ Uploading status } & $\mathbf{1 5 8}$ & $\mathbf{1 0 0 . 0}$ & $\mathbf{1 0 0 . 0}$ & \\
\hline
\end{tabular}

TABLE 2: Social Networking helps for professional Grooming

\begin{tabular}{|c|c|c|c|c|c|}
\hline \multicolumn{2}{|c|}{ Response } & Frequency & Percent & $\begin{array}{c}\text { Valid } \\
\text { Percent }\end{array}$ & $\begin{array}{c}\text { Cumulative } \\
\text { Percent }\end{array}$ \\
\hline Valid & Strongly agree & 20 & 12.7 & 12.7 & 12.7 \\
\hline & Agree & 72 & 45.6 & 45.6 & 58.2 \\
\hline & Neutral & 46 & 29.1 & 29.1 & 87.3 \\
\hline & Disagree & 15 & 9.5 & 9.5 & 96.8 \\
\hline & Strongly disagree & 5 & 3.2 & 3.2 & 100.0 \\
\hline & Total & 158 & 100.0 & 100.0 & \\
\hline
\end{tabular}

Source: Secondary Data (Questionnaire)
TABLE 3: Social networking Sites not aware by students

\begin{tabular}{l} 
TABLE 3: Social networking Sites not aware by students \\
\begin{tabular}{|l|l|r|r|r|r|}
\hline \multicolumn{2}{|l|}{ Response } & Frequency & Percent & Valid Percent & $\begin{array}{c}\text { Cumulative } \\
\text { Percent }\end{array}$ \\
\hline Valid & Google+ & 18 & 11.4 & 11.4 & 11.4 \\
\hline & $\begin{array}{l}\text { Live } \\
\text { journal }\end{array}$ & 28 & 17.7 & 17.7 & 29.1 \\
\hline & Quora & 12 & 7.6 & 7.6 & 36.7 \\
\hline & Qzone & 30 & 19.0 & 19.0 & 55.7 \\
\hline & Skype & 11 & 7.0 & 7.0 & 62.7 \\
\hline & Snapchat & 9 & 5.7 & 5.7 & 68.4 \\
\hline & Tumblr & $\mathbf{5 0}$ & $\mathbf{3 1 . 6}$ & $\mathbf{3 1 . 6}$ & $\mathbf{1 0 0 . 0}$ \\
\hline
\end{tabular} \\
\hline
\end{tabular}

TABLE 4: Most visited social networking sites by students

\begin{tabular}{|c|c|c|c|c|c|c|}
\hline \multicolumn{2}{|c|}{ Response } & Frequency & Percent & Valid Percent & $\begin{array}{l}\text { Cumulative } \\
\text { Percent }\end{array}$ & Rank \\
\hline Valid & FB & 20 & 12.7 & 12.7 & 12.7 & 4 \\
\hline & INSTA & 58 & 36.7 & 36.7 & 49.4 & 1 \\
\hline & WATSAPP & 34 & 21.5 & 21.5 & 70.9 & 2 \\
\hline & Google + & 8 & 5.1 & 5.1 & 75.9 & 5 \\
\hline & Youtube & 38 & 24.1 & 24.1 & 100.0 & 3 \\
\hline & Total & 158 & 100.0 & 100.0 & & \\
\hline
\end{tabular}

Barchart:1

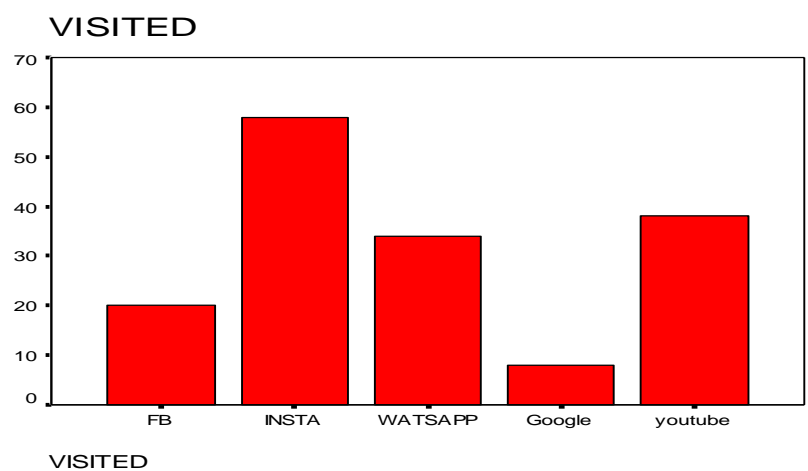

Source: Secondary Data (Questionnaire)

\section{Karl Pearson's Correlation}

\section{Null hypothesis(HO):}

There is a positive relationship between the Education pursuing by students and the purpose of students using social networking sites.

\section{Alternate hypothesis (H1):}

There is a negative relationship between the Education pursuing by students and the purpose students using of social networking sites.

TABLE6: Correlation Analysis

\begin{tabular}{|l|l|r|r|}
\hline & & \multicolumn{1}{|c|}{ PURPOSE } & EDUCATION \\
\hline PURPOSE & $\begin{array}{l}\text { Pearson } \\
\text { Correlation }\end{array}$ & 1 & $-.213\left(^{* *}\right)$ \\
\cline { 2 - 4 } & Sig. (2-tailed) & & .007 \\
\cline { 2 - 4 } & $\mathrm{N}$ & 158 & 158 \\
\hline \multirow{5}{*}{ EDUCATION } & $\begin{array}{l}\text { Pearson } \\
\text { Correlation }\end{array}$ & $-.213\left({ }^{* *}\right)$ & 1 \\
\cline { 2 - 4 } & Sig. (2-tailed) & .007 & \\
\cline { 2 - 4 } & $\mathrm{N}$ & 158 & 158 \\
\hline
\end{tabular}


Inference: From the above table it is inferred that there is a negative relationship exists between the Education pursued by the students and the purpose of students using of social networking sites. Hence Alternate Hypothesis (H1) is Accepted.

\section{Simple Linear Regression}

\section{Null Hypothesis, HO:}

There is no association between the Gender and the students using social networking sites using Linear Regression.

\section{Alternate Hypothesis, H1:}

There is an association between the Gender and the students using social networking sites using Linear Regression.

TABLE7: Gender and use of social networking

\begin{tabular}{|l|c|r|r|r|}
\hline $\begin{array}{l}\text { Mode } \\
1\end{array}$ & $\mathrm{R}$ & R Square & $\begin{array}{c}\text { Adjusted } \\
\text { R Square }\end{array}$ & $\begin{array}{c}\text { Std. Error } \\
\text { of the } \\
\text { Estimate }\end{array}$ \\
\hline 1 & $.274(\mathrm{a})$ & .075 & .069 & .483 \\
\hline
\end{tabular}

\begin{tabular}{|c|c|c|c|c|c|c|}
\hline Model & & $\begin{array}{l}\text { Sum of } \\
\text { Squares }\end{array}$ & $\mathrm{df}$ & $\begin{array}{c}\text { Mean } \\
\text { Square }\end{array}$ & $\mathrm{F}$ & Sig. \\
\hline 1 & $\begin{array}{l}\text { Regressio } \\
n\end{array}$ & 2.962 & 1 & \multirow{3}{*}{$\begin{array}{r}2.962 \\
.234\end{array}$} & \multirow[t]{3}{*}{12.679} & \multirow[t]{3}{*}{$.000(a)$} \\
\hline & Residual & 36.437 & 156 & & & \\
\hline & Total & 39.399 & 157 & & & \\
\hline
\end{tabular}

\begin{tabular}{|c|c|c|c|c|c|c|}
\hline \multirow[t]{2}{*}{$\begin{array}{l}\text { Mode } \\
1\end{array}$} & & \multicolumn{2}{|c|}{$\begin{array}{c}\text { Unstandardized } \\
\text { Coefficients }\end{array}$} & \multirow{2}{*}{$\begin{array}{c}\text { Standardized } \\
\text { Coefficients } \\
\text { Beta }\end{array}$} & \multirow[t]{2}{*}{$\mathrm{t}$} & \multirow[t]{2}{*}{ Sig. } \\
\hline & & B & $\begin{array}{l}\text { Std. } \\
\text { Error }\end{array}$ & & & \\
\hline 1 & (Constant & 1.816 & .090 & & 20.118 & .000 \\
\hline & VISITED & -.100 & .028 & -.274 & -3.561 & .000 \\
\hline
\end{tabular}

\section{Inference:}

The $\mathrm{R}$ value in the table represents the simple regression is 0.274 , which indicates the degree of correlation. Here the value $\mathrm{p}<0.000$, which is lesser than 0.5 , it indicates that there is an association between the Gender and the usage of social networking sites by students.

\section{One-Way ANOVA}

\section{Null Hypothesis, $\mathrm{HO}$ :}

There is no relationship between the Educationand the student's opinion on professional grooming using social networking.

\section{Alternate Hypothesis, H1:}

There is a relationship between the Educationand the student's opinion on professional grooming using social networking.

Table 8: Education vs Professional Grooming

\begin{tabular}{|l|r|r|r|r|r|}
\hline & $\begin{array}{c}\text { Sum of } \\
\text { Squares }\end{array}$ & \multicolumn{1}{c|}{ df } & \multicolumn{1}{c|}{$\begin{array}{c}\text { Mean } \\
\text { Square }\end{array}$} & \multicolumn{1}{c|}{ F } & Sig. \\
\hline Between & 6.651 & 4 & 1.663 & 3.493 & .009 \\
Groups & 72.824 & 153 & .476 & & \\
Within Groups & 79.475 & 157 & & & \\
Total & & & & \\
\hline
\end{tabular}

Inference:
From the ANOVA table it is inferred that Decision: $\mathrm{P}$ value $(0.009)$ is lesser than 0.05 , Thus there is a relationship between the Educationand the student's opinion on professional grooming using social networking.

\section{FINDINGS}

- $\quad$ From the analysis it is inferred that about $66 \%$ of the students use the social networking site for the friendship connect.

- About $50 \%$ of the students not aware about the social networking site like Tumblr, Qzone.

- Nearly $58 \%$ of the students visit mostly Instagram as a part of networking compared with FB and WhatsApp.

- The students of about $98 \%$ agree that social networking sites are helpful in learning new things.

- Using correlationit is inferred that there is a negative relationship exists between the Education pursued by the students and the purpose of students using of social networking sites.

- $\quad$ From the regression analysis it is found that there is an association between the Gender and the usage of social networking sites by students.

- In the one-way ANOVA analysis, it is inferred that there exists a relationship between the Educationand the student's opinion on professional grooming using social networking.

\section{SUGGESTIONS}

- The purpose of using social networking sites and its benefits to be created awareness among students by the academicians which helps to make students to have a disciplined behavior in social networking forum.

- Many Journal and live social networking with professionals / Industry Experts in the social networking helps the students to focus on placement opportunities, new project areas, get business ideas \& support for the startups and to know the latest innovation in the field.

\section{CONCLUSION}

From the above study, we can identify the interest of majority students towards Social networking and their usage patterns. It is also found that majority of the students use it only for friendship connect and share their personal activities as it was felt as very essential in the social networking platform. The perception of the students to be changed about the social networking sites as some of thesites also involve in the professional grooming and supports for knowledge enrichment.

\section{REFERENCES}

1. International journal of social media and interactive learning environments.

2. Journal of mass communication and Journalism.

Books

1. India social. 